\title{
THE LEADER APPROACH ACROSS THE EUROPEAN UNION: ONE METHOD OF RURAL DEVELOPMENT, MANY FORMS OF IMPLEMENTATION
}

\author{
Ondřej Konečný 1
}

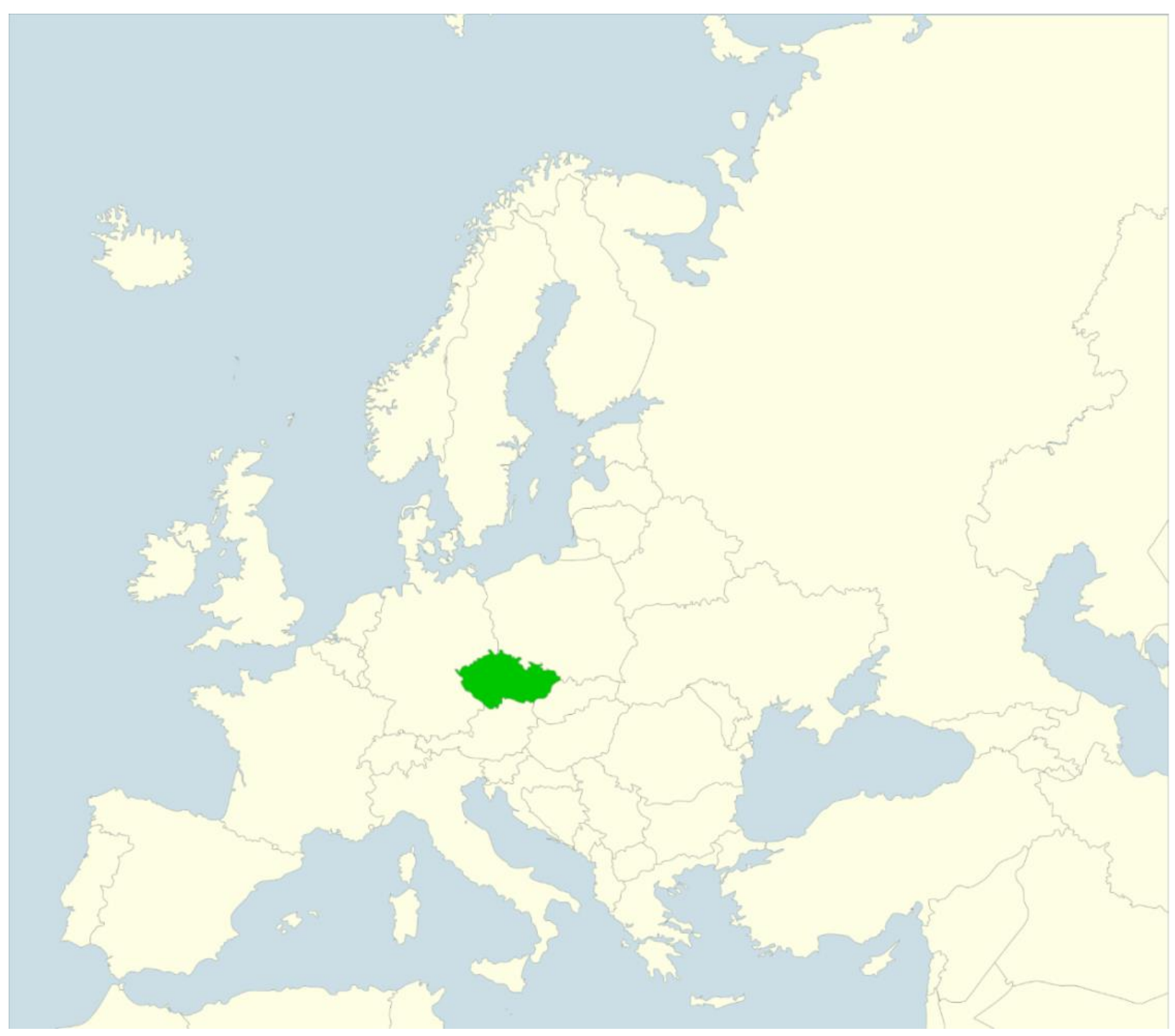

\footnotetext{
${ }^{1}$ Mgr. Ondřej Konečný, Ph.D., Department of Regional Development and Public Administration, Faculty of Regional Development and International Studies, Mendel University in Brno, třída Generála Píky 2005/7, 61300 Brno, Czechia, e-mail: ondrej.konecny@mendelu.cz. ORCID: 0000-0003-3098-7726
} 
Abstract: After the accession of the ten new member states to the EU in 2004 and the following membership of Bulgaria and Romania in 2007, the (neo)endogenous development method LEADER has become pan-European. LEADER was implemented in all EU countries in the period 2007-2013, however, its application and potential to impact rural areas differed from country to country. Therefore, the aim of the article is to describe these differences on the basis of support outputs of LEADER under Axis 4 of the Rural Development Programs in 2007-2013. Respecting different path dependencies of the EU states, the article demonstrates the differences in the implementation of this method in two basic territorial units of the EU member states according to the length of the EU membership, as well as the length of experience in implementation of the LEADER method. The scope of LEADER implementation and the potential impact significantly differed between the old and new member states, and the internal heterogeneity of groups is also evident. On the one hand, lack of embeddedness of the method is manifested among the EU12 states (the need for dynamic growth of institutional capacity), on the other hand, socio-economic and political factors modify scope, potential impact and way of implementation of the method in individual countries.

Key Words: LEADER, Neo-endogenous Development, Local Action Group, European Union, the Program of Rural Development

Souhrn: Vstupem deseti nových členských států do EU v roce 2004 a následným členstvím Bulharska a Rumunska od roku 2007 se metoda (neo)endogenního rozvoje LEADER stala skutečně panevropskou. Přestože metoda byla v období 2007-2013 implementována ve všech státech $E U$, její uplatnění a potenciál dopadu ve venkovském prostoru se $v$ jednotlivých státech velmi lišil. Cílem článku je proto na základě výstupů podpory LEADER v rámci osy 4 Programů rozvoje venkova v období 2007-2013 odhalit tyto diference. Respektujíce odlišné trajektorie států EU, článek ukazuje rozdíly $\mathrm{v}$ implementaci metody ve dvou základních územních jednotkách skupin států EU dle délky zkušenosti s členstvím v EU (resp. implementací metody LEADER). Rozsah implementace LEADERu a potenciální dopad mezi tzv. původními a novými členskými státy se významně lišil, vnitřní heterogenita skupin je však taktéž evidentní. Na jednu stranu se tak projevuje (ne)zakořeněnost této metody mezi státy EU12 (potřeba dynamického růstu institucionální kapacity), ale na druhé straně socioekonomické a politické faktory modifikují přístupy jednotlivých států $\mathrm{k}$ implementaci metody.

Klíčová slova: LEADER, neo-endogenní rozvoj, místní akční skupina, Evropská unie, program rozvoje venkova

\section{Introduction}

The (neo-endogenous) approach to rural development has become pan-European after the accession of ten countries to the European Union in 2004. The LEADER method initiated in the 1990s spread to most European countries. While the so-called old EU member states had applied the method already in several programming periods, for the countries that acceded after 2003, it represented an entirely new approach of engaging the local community in rural development and actively contributing to the initiation of a "functioning" local partnership (Hudečková and Lošták, 2008). However, the time gap of implementation also represented an advantage for the new member states as they could learn from the old member countries how to tackle difficulties in the process of implementation. The post-socialist states had to learn how to work with new options to support rural development brought by the EU method, and unlike other countries such as Finland, France or Scotland, the EU-12 states did not have much experience with other bottom-up methods prior to implementing LEADER (Ray, 2000). 
The socialist arrangement of most of the new member states influenced the low interest of local people to be active in local events and development (Majerová, 2009; Marquardt et al., 2012). Thus in these countries, implementation of the LEADER method also represented the possibility to restore confidence, activity, interest and participation among various subjects operating at local level. Lošták and Hudečková (2010) demonstrated that activation of people in rural communities was observed following the implementation of LEADER+. Therefore, the transferability of the approach to the Central and Eastern European countries (CEECs) preparing for the EU membership was broadly discussed (Ray, 2000; Maurel, 2008; Chevalier and Maurel, 2010).

It was not only the enlargement of the EU in 2004 which led to the so-called mainstreaming of LEADER in European rural space as a key approach to stabilization and development of rural areas (Navarro et al., 2015; Dax et al., 2016). Sufficient financial security also affected the enormous growth of the number of Local Action Groups (LAGs) in most of the European Union countries, especially in the period 2007-2013 (Chevalier, 2012). A considerable number of newly supported groups became active bearers and implementers of participative development ideas. Subsequently, the impact of LAG-supported activities increased, and in some countries more than half of the rural population lived in territories where some of the groups actually operated.

In spite of this dominant trend, it is appropriate to anticipate significant differences in scope and mode of implementation between European Union member states (Chevalier et al., 2017). The miscellaneous historical and social development of European countries has conditioned the degree of social readiness to adopt the method and general commitment to public affairs. Different political arrangements and political discourse also implied differing perception of the need to adjust the regulation and overall framework of rural development support through the Rural Development Program (RDP) and LEADER (Osti, 2000; Chevalier and Maurel, 2010; Convery et al., 2010; Navarro et al., 2015). Geography of each country plays its role, whether in terms of the size of the rural area (potential impact on the population), the form of agriculture and its conditions, or the functional relationships within the territory (population and area size of LAGs) (Chevalier, 2012).

The factors outlined above reflect in the experience with the LEADER method, in the spatial arrangement of institutions and the potential size of population benefiting from advantages of the method implementation. Although individual studies focusing specifically on the application of the method in one territory/state (Böcher, 2008; Macken-Walsh and Curtin, 2012; Fakowski, 2013) or a comparison of several territories (Navarro et al., 2015; Dax et al., 2016; Chevalier et al., 2017) are widely presented to the public, comparative studies focusing on the entire area of the European Union remain isolated (Dax and Oedl-Wieser, 2016). Such a study is presented by Chavealier (2012), showing the differences between countries in the years 2007-2013 from many point of views (number and size of LAGs, approach to LAG selection and the overall process of method implementation). However, in the available literature, there is still a lack of understanding of different approaches of the countries in terms of the LEADER method potential impacts and the possible supported themes.

The following questions arise, such as: Given their inexperience, were the countries joining the EU after 2003able to cope "quantitatively" with neo-endogenous methods of rural development? Do the EU15 member states apply the method to larger extent than EU12 (if expressed as a proportion of the funding targeted for this axis), and is the potential impact on local people higher if the majority of them live in the LAGs territories? Did the EU countries apply varied thematic targeting of local support through LAGs? Therefore, the key objective of the presented study is to identify differences in the extent of support and its potential impact on the population (1) and in the strategic setting of the supported LEADER measures (2) among the member states, and also compare the groups of the so-called old EU15 and new EU12 member states. Such pan-European comparison contributes to the current discussions concerning LEADER. It is assumed that different political, social, economic and geographic factors mentioned above and the various path dependence of individual states influenced regional differentiation of LEADER implementation. 


\section{Theoretical background: Geography of LEADER}

Rural area is not a united space, not only at the European, but also at the national level (Perlín et al., 2010). Therefore, the European countries use different mechanisms to stabilize and improve the quality of life in rural areas in the era of advancing globalization (Woods and McDonagh, 2011). As demonstrated by the annually published Regional Yearbook of Eurostat, the political, economic and social characteristics of each country are diverse. Nevertheless, the membership in the European Union and the adoption of regional policy and Common Agricultural Policy partially unified these fragmented and multiple approaches, and turned the attention to 'neoendogenous development' (Ray, 2000). Fulfilment of the set goals and implementation of uniformly set methodologies have also been reflected in the approach to the development of rural areas. As Pospěch (2014) demonstrated on the example of the post-socialist Czech Republic, rural development was strongly linked with agriculture before 1989. After the "period of selfsearching in the first half of the nineties, the "Europeanisation of the rural discourse" became dominant. The Czech rural policy was integrated in the common European discourse, and simultaneously, more bottom-up-oriented policy approach was introduced.

The acceptance of the LEADER method as an important element in the rural space was commented on as a mainstreaming of this method in the European approach to rural development (Pollermann et al., 2013; Navarro et al., 2015), and LEADER was called pan-European method (Ray, 2000). Due to the lack of experience with the method or similar elements, the Central, Eastern and some Southern European countries (entering the EU in 2004) were perceived as a laboratory for the application of this approach, which was proven and popularized in many of the old member states (Kovách, 2000). In fact, also the EU15 states have provided an opportunity for LEADER to verify its suitability and they can be seen as the first laboratory space of new (neoendogenous) approaches to European rural development.

As shown by Granberg et al. (2015), the broad focus on LEADER and LAGs enables to reveal significant differences in the application of this method across countries in a number of relevant scientific disciplines. Therefore, it is appropriate to talk about the geography of the LEADER and the dynamic development of this young (niche) discipline. Leaving aside the disparity resulting from the geographical conditions, previously published studies clearly illustrate the diverse approaches of national and regional authorities to lack of) control of the implementation of LEADER. While Navarro, Woods and Cejudo (2015) capture the regional government's attempt to control this method in Andalusia (Spain) and Wales, the whole implementation is dominated by the national level in Hungary (Chevalier, 2012). In some countries, the regional governments directly negotiated the form of the Rural Development Program with the European Commission (France, Germany, Poland...) while the process was centrally/nationally managed in most EU countries (Böcher, 2008; Chevalier, 2012). However, examples from some countries demonstrate a relative autonomy in the actual implementation. Many studies are linked to the study of governance (Furmankiewicz, 2012; Macken-Walsh and Curtin, 2012; Marquardt et al., 2012; Thuesen and Nielsen, 2014). Böcher (2008) on the example of Germany shows that the differences may also occur within one country. While the method is related with the development of governance approach in the western part of Germany, LAGs are rather understood as other subsidizing agencies in the eastern part of country. Therefore, LAGs are often viewed as a source of finance instead of a platform of mutual cooperation (and LEADER principles). Similar approach to the LEADER application can be seen in other Central and Eastern European countries which experienced the post-socialist path dependency (Marquardt et al., 2012; Svobodová, 2015; Boukalová et al., 2016). Influence of regional and national governments is highlighted in the views critical of connecting the method with the bottom-up approach of development (Margarian, 2013). Therefore, many authors suggest that the method is rather a mix of top-down and bottom-up approaches (Convery et al., 2010; Navarro et al., 2015; Dax et al., 2016).

Regional differentiation is also evident in the management and applied strategic approaches of local action groups (Rizzo, 2013). Local government representatives play a key role in many LAGs in the Central and Eastern European countries since they refuse to lose their influence on the direction of (financial) support in the location where they operate (Maurel, 2008; 
Furmankiewicz et al., 2010; Marquardt et al., 2012; Fakowski, 2013). Representatives of private companies and farmers have a lower impact in the CEECs (Lošták and Hudečková, 2010; Delin, 2012), while in Italy or Spain, farmers-sector professionals are noticeably present with a high involvement of a private initiative (Chevalier, 2012). The principles of LEADER are also fulfilled selectively (Thuesen and Nielsen, 2014; Bumbálová et al., 2016), and the differences between the LAGs are evident even in the case of supported themes and perceived positive and negative effects of the LEADER method (Lošták and Hudečková, 2010; Volk and Bojnec 2014; Nevěděl and Horák, 2015;Svobodová, 2015).

Although experts agree that the idea of LEADER is oriented towards the development of capacities, skills, cooperation and perspectives of local people (Ray, 2000), reality differs from country to country. The quality of social capital as one of the key attributes to successful rural development through the LEADER method (Furmankiewicz et al., 2010; Jančák et al., 2010; Marquardt et al., 2012) is significantly differentiated in Europe. In a number of countries that joined the EU since 2004, the social capital is relatively low and capacities of local actors are needed (Lošták and Hudečková 2008; Volk and Bojnec 2014). As Lowe (2000) indicates, the limited capacity of rural areas and skills of rural populations to participate in economic and development activities are the main problem. Therefore, an idea of cultural and social innovation seems to be idealized rather than actual output of this method in many European states (Dargan and Shucksmith, 2008). As the studies in Pisani et al. (2017) show, understanding of social innovation within the LEADER method implementation vary between the member states, and in some countries this concept is more formally and "purposefully" fulfilled (Chevalier, 2012; Bumbálová et al., 2016). The social innovation is not aspatial activity and it is linked to territory (Dax and OedlWieser, 2016). Therefore, the geography and location play a significant role also in the creation of this type of innovation.

Geographical methods of assessing LAG activities in certain location are usually used to identify supported projects and local networks. Partial studies from individual countries suggest that LEADER tends to be concentrated in the developed local centres (Lukić and Obad, 2016). However, the LEADER method is considered to be exclusively rural (Buller, 1998; Dargan and Shucksmith, 2008). It is therefore appropriate to ask whether implementation of the method can reduce inter-regional disparities. Cañete, Navarro and Cejudo (2018) demonstrate on the example of Andalusia in Spain that regional differences are increasing due to the method, since the depressed rural regions are not those locations where the LEADER support is concentrated. According to Masot and Alonso (2017), LEADER positively discriminates the most developed areas because significant investments were made in LAGs and cities where industrial and service sectors are highly developed due to their proximity to major cities of the region. Margarian (2013) believes that such localized approaches fail to compensate rural areas for lack of agglomeration advantages. Therefore, the reduction of differences between core and peripheral territories cannot be expected. However, as Tulla, Vera, Valldeperas and Guirado (2017) stated, peripheral regions have the opportunity to locate economic activities with comparative advantage due to LEADER. Small villages operate within village associations or as part of local action groups in order to overcome limitation of insufficient financial and human resources (Št'astná and Vaishar, 2017). Thus, the LEADER implementation is a struggle for control over the distribution of resources between the centre and periphery (Osti, 2000).

\section{Data and methods}

The geography of the LEADER method in individual member states and the monitored group of so-called "old and new" EU member states is based on a comparison of indicators capturing the situation in two different points of views:

- Potential importance of the method in the territory:

$\circ$ amount of people living in the LAG territory;

- share of LEADER funding under RDP;

- recalculation of LEADER expenditures per capita. 
- Strategic orientation of the LEADER method according to the supported measures:

- targeted support according to the importance of individual axes;

o the ratio of supported projects (M411-Competitiveness, M412-Environment/land management and M413-Quality of life/diversification) to the expenditures on M431 Running the LAG, skills acquisition, animation and M421 Implementing cooperation projects.

The average values per LAG (average population, projects, and finances) are also calculated and compared. The author uses both the comparisons of indicators calculated for each country, as well as the EU12 monitored group (EU accession countries after 2003 - see Figure 1) and EU15. The applied assessment of differences between states and between the selected two groups is motivated by different LEADER experience and embeddedness in the structure of the European community. The concept of the "old" and "new" EU member states is used in a number of studies showing differences between the countries, or groups (Hudečková and Lošták, 2008; Chevalier and Maurel, 2010; Furmankiewicz, 2012; Marquardt et al., 2012).

Author of this paper processed pre-prepared data published by The European Network for Rural Development (ENRD). The final analysed dataset is created on the basis of two databases related to RDP: a) the 2007-2013 output indicators (ENRD 2015b), and b) Financial and physical indicators 2007-2013 (ENRD 2015a). The output indicators were designed to measure the activities directly realised within the programme's measures. Based on the database, the number of LAGs, total population in a LAG area and the number of projects financed by LAGs was obtained. Financial and physical indicators, including Total Public Expenditure and EAFRD contribution are aggregated (level of member state) in order to show the progress of the RDP expenditures per axis and measure in the years 2007 to 2013.

Based on the applied assessment, it is necessary to specify several limitations of the used data. The population of the state was founded on the sum of population living in so-called predominantly rural and intermediate regions as classified by Eurostat within the Urban-rural typology. Due to the small population size of Malta, the total population of the country was considered. It means that the population of urban areas (the so-called predominantly urban regions) was not included as the potential population receiving the benefits of LEADER. Although the area characteristics are widely reported in research (Arabatzis et al., 2010; Chevalier, 2012), they are not used in the article. LEADER initiative is especially connected to communities, not territories. Therefore, possible impact is related to the number of potential residents participating in the method implementation rather than to the area. In addition, some mistakes were discovered during the data verification in the core statistical database (e.g., the figure of LAGs in Spain showed a value larger than the size of the whole country).

Indicators of the RDP financial implementation through the LEADER method capture the state of implementation of total public expenditures. Rather marginal attention is paid to planned expenditures, which were designed before the actual implementation. In terms of interpretation, it is important to realize that no EU member state had exhausted the whole allocation according to the most up-to-date available data (June 2015). Some countries did not even reach half of the planned financial allocations (Bulgaria, Cyprus, Malta, Romania and Greece) for axis 4 of the RDP. Inappropriate targeting and planning of the program, unpreparedness and the lack of statistical information should be mentioned as reasons of this situation. Since some EU countries did not implement one "national" RDP, the expenditures are the sum of the individual/regional RDPs in these states (see Chevalier, 2012). Also, the number of projects supported via the implementation of LEADER is evaluated. However, even in the case of this indicator, it is necessary to take into account the above-mentioned limitations. After the verification process, the available characteristic of the number of recipients was not analysed, because the figure is closely related to the number of supported projects. The number of projects and recipients were the same in nine countries (the number of projects reached $70 \%$ of beneficiaries across the EU), and the data was not available for all member states. The recalculation of expenditures per capita relates only to expenditure on projects under the three measures (M411, 412 and 413) and not to the volume of LEADER funds as a whole. It means that allocation aimed for M431 Running 
the LAG, skills acquisition, animation, and M421 Projects implementation is not included in this calculation, since the impact on the population and rural space is not evident.

\section{Results and Discussion}

\subsection{The size of Local Action Groups in the European Union}

Although the EU12 countries only had a short period to acquaint with LEADER, the size of guaranteed allocation caused the institutional capacity (expressed by the number of LAGs or populations living in their territories) to exceed the importance according to the population living in predominantly rural and intermediate regions of the EU (Figure 1). In countries that acceded to the EU in 2004 and 2007, despite the short period, a sufficient institutional capacity to utilize the support for development of rural areas was created (the difference in the proportion of countries according to the number of LAGs and population). In 2000-2006, the EU15 member states dominated in the sphere of the LAGs or the covered population. In the following period up to 2013 , institutions were more intensively complemented and population was more intensively covered in countries that fully utilized it for the first time (Chevalier, 2012). In these states, we can talk about the "boom" of institutionalized neo-endogenous development at the end of the first decade of $21^{\text {st }}$ century and real mainstreaming of this rural development method (Furmankiewicz et al., 2010; Lošták and Hudečková, 2010; Marquard et al., 2012). Despite this faster tempo, the differences between EU15 and EU12 in terms of the size of implementation still showed a weak position of the new member states. It means that $61 \%$ LAGs were localized in EU15, in which $71 \%$ of EU LAGs population lived.

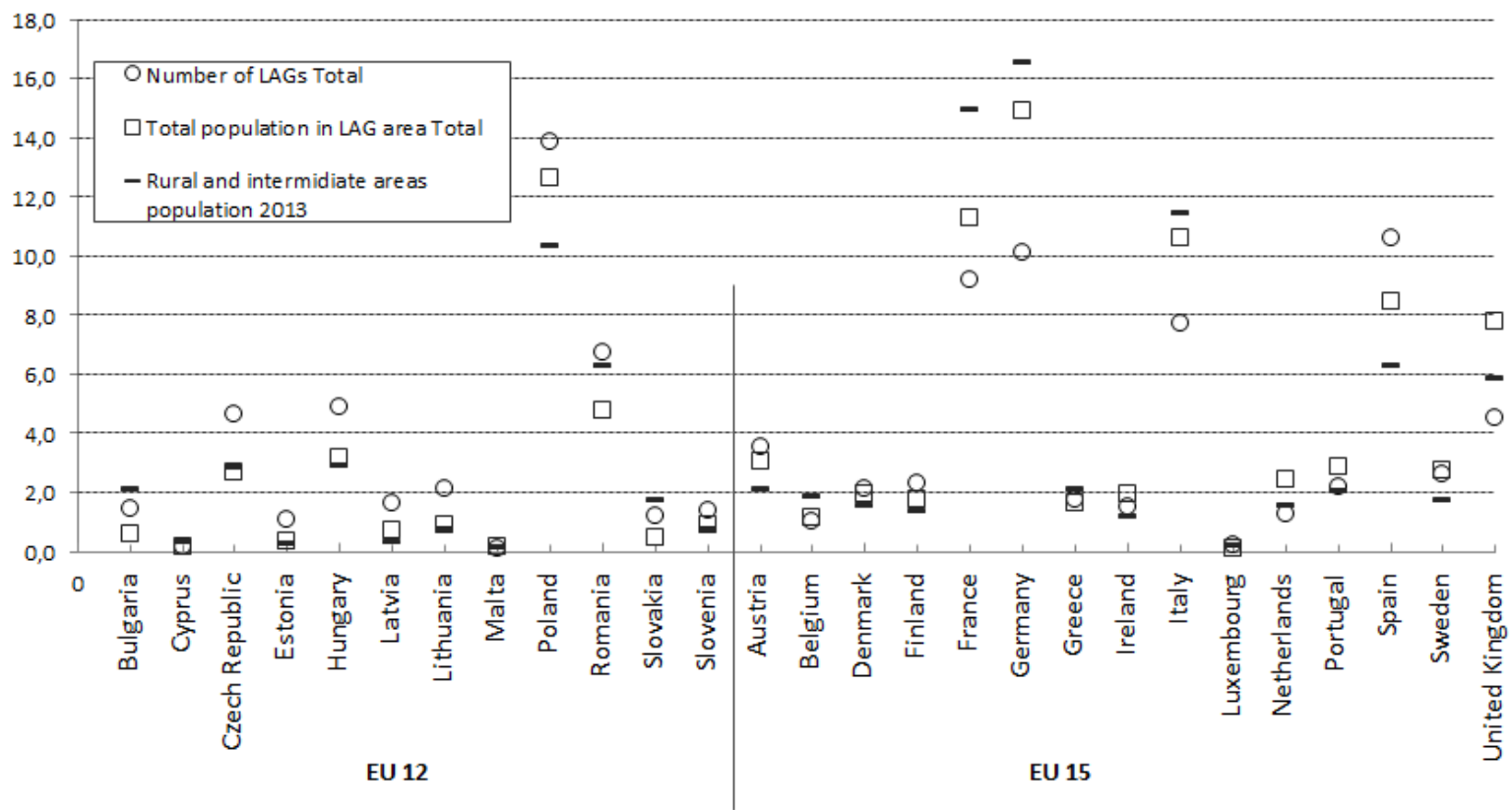

Fig 1. Share of member state on the EU total in 2007-2013 [\%] in selected characteristics: number of LAGs; population in LAGs; and rural and intermediate areas population. Source: processed by author based on ENRD 2015 (a,b) and EUROSTAT.

LEADER implementation is also significantly spatially concentrated, especially in the EU12 states (Figure 2 and 3). However, it respects the uneven concentration of the overall population in individual states and the domination of some states within the group. For example, among the 2004 accession countries, Poland itself concentrated almost half of the LAGs and the population living in them. No other state of EU15 occupies such a dominant position among the old member countries. France, Italy, Germany, Spain and the United Kingdom cumulate close to $70 \%$ of the LAGs of this group. Therefore, it is not surprising that scientific literature on local development and implementation of the LEADER method pay particular attention to these states (Osti, 2000; Böcher, 2008; Convery et al., 2010; Navarro et al., 2015). 

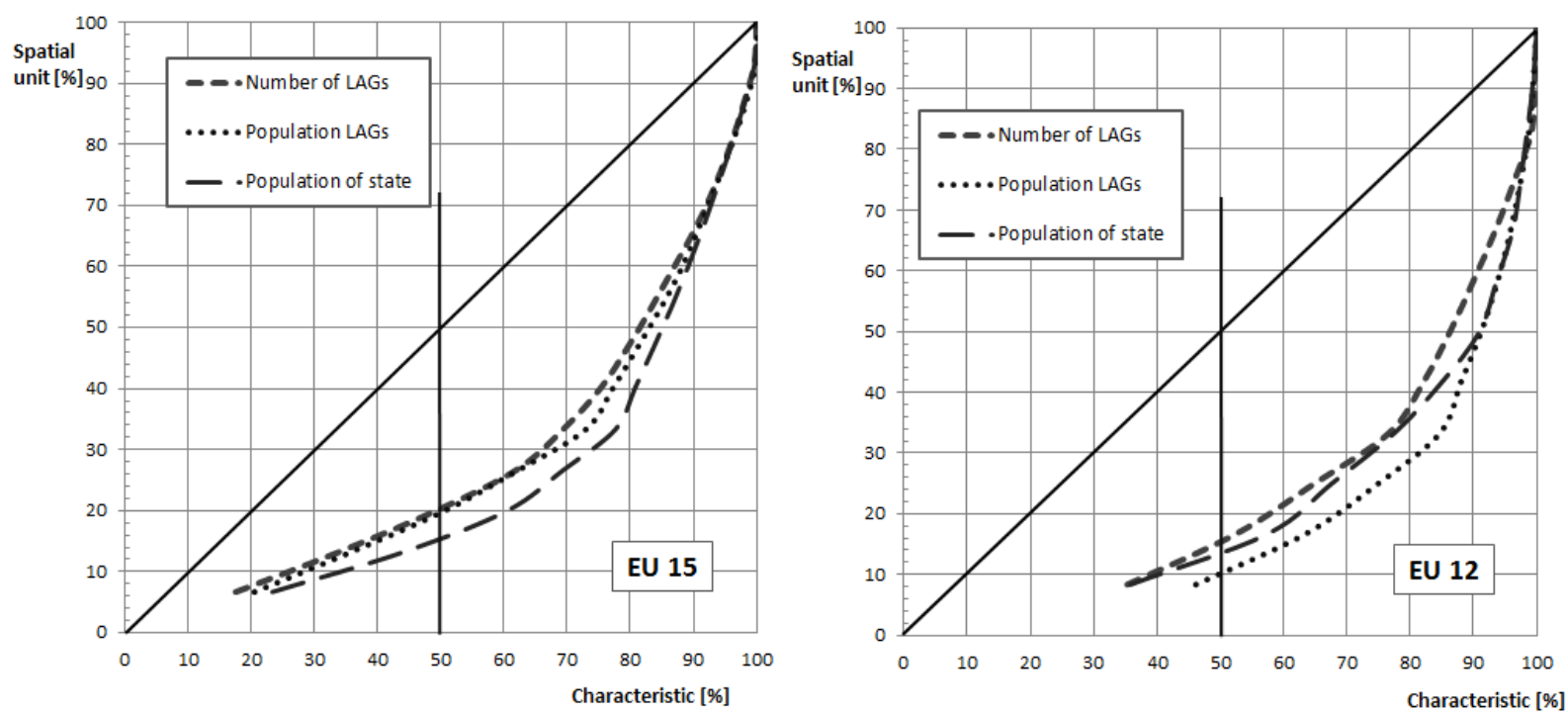

Fig 2., Fig 3. Spatial concentration of selected characteristics of LAGs in the groups of EU states in the period 20072013. Source: processed by author based on ENRD $2015(a, b)$ and EUROSTAT

\subsection{Potential Impact of LEADER Method}

Given the relative share of resources earmarked for axis 4 of the RDP, it may be inferred that individual member states of the European Union are highly aware of the need and importance of participative rural development. Countries with a long experience of implementation of LEADER have allocated a greater share of funding to rural support through this method. The share of the planned and implemented amount of funds for LEADER in the context of RDP exceeded more than 1.5 times the level recorded in the states that joined the EU in 2004 and 2007. Only Estonia reached similar value as the "opened to the method" states of the EU15, and only the Czech Republic and Lithuania implemented expenditures at least above the average of the European Union. Although many authors cited the LEADER mainstreaming in rural development (Pollermann et al., 2013; Dax et al., 2016), the share of the expenditures for this method within the entire RDP was not accordingly important and was far from half of the allocation (Fig 4).

Even in countries such as Denmark or the Netherlands, most favourably disposed to the method, the figure rose only to about $10 \%$ of RDP. It was mainly the newly admitted and Southern European countries which decided not to devote so much space to LEADER and rather employed traditional support mechanisms through centralized institutions (Rizzo, 2013). As shown by Papadopoulou, Hasanagas and Harvey (2011) on the example of Greece, the LEADER method implementation was not necessarily very different from other development programs.

The EU12 countries made public expenditures in this area at just one-fifth of the European Union, although their total RDP expenditures represented $30 \%$ of the EU-wide spending. The greater confidence of the old member states to relate rural development funds through this participatory method is evident. Only one EU12 country - Poland, is ranked among the ten EU member states which recorded the highest share of expenditures in the EU as a whole. However, Poland's 8 per cent share does not correspond to the importance of the LAGs or population living in their territory. It is important to note that although this paper is based on the latest data available for the period 2007-2013, many states were significantly behind the spending plans of implementation. It is therefore the reason why France declared lower LEADER expenditures than smaller countries, e.g. Austria or Portugal. 


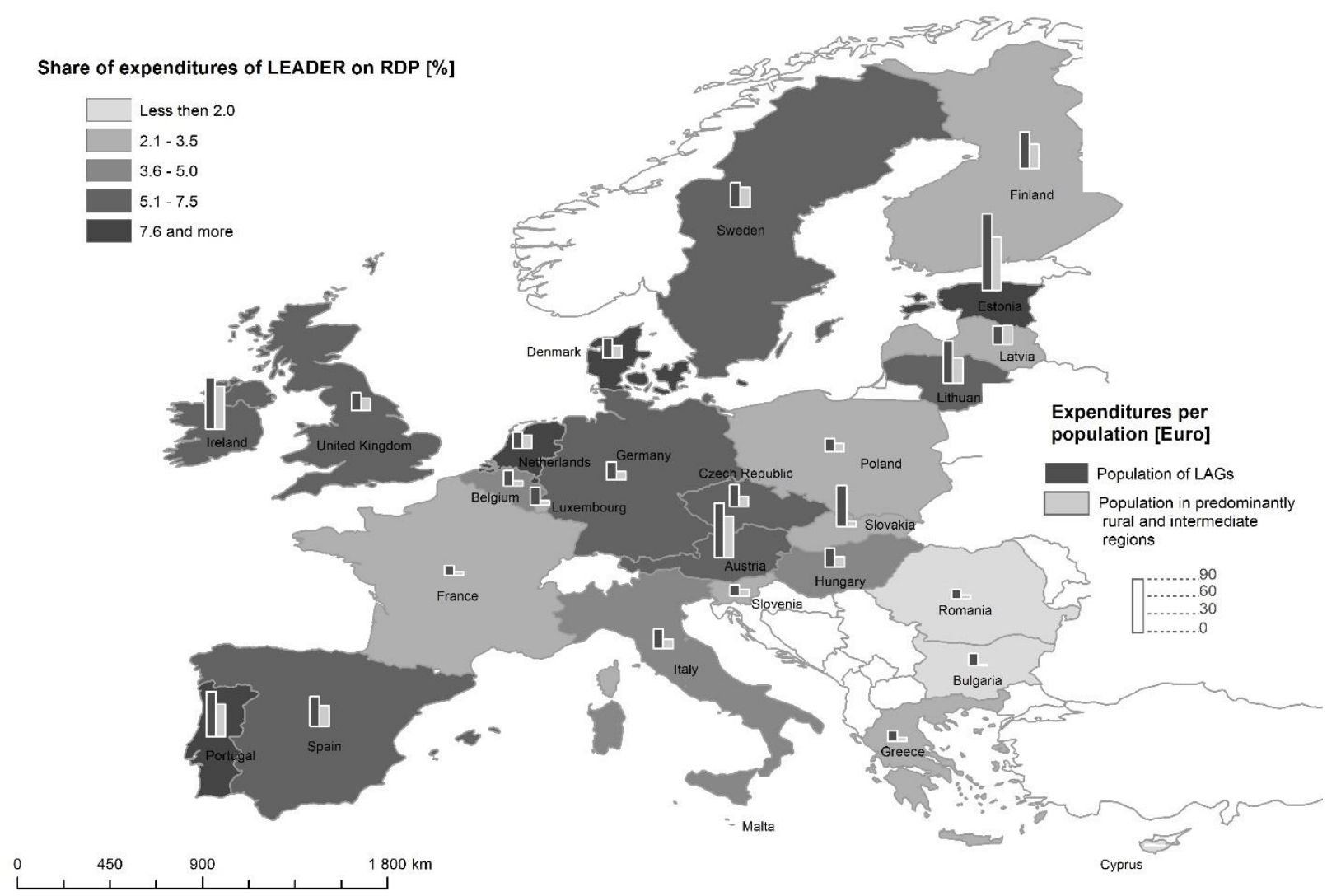

Fig 4. Importance of LEADER in relation to RDP and population across the EU member states in 20072013. Source: processed by author based on ENRD $2015(a, b)$ and EUROSTAT

Impact of the LEADER method implementation on individual regions is primarily conditioned by the number of people living in LAG territories. In the Europe-wide context, significant differences in the size of population which could be actively influenced are reported. While in Bulgaria and Slovakia, the share of population of LAGs was close to only $1 / 10$, at least $4 / 5$ of the population lived in LAGs in Austria, Ireland, Latvia, the Netherlands, and Sweden. The old member states can be found amongst the countries with high percentage of population thus affected by LEADER. However, despite the weaker implementation experience, the new member states were able to support and institutionalize the LAGs to such an extent that the share of non-urban population of LAGs was almost comparable in EU12 and EU15.

Tab 1. Selected characteristics showing the potential impact of LEADER in the EU in 2007-2013. Source: processed by author based on ENRD $2015(a, b)$ and EUROSTAT

\begin{tabular}{|l|r|r|r|r|r|r|r|}
\hline Indicator & \multicolumn{2}{|c|}{$\begin{array}{c}\text { Share of } \\
\text { expenditures of } \\
\text { LEADER on RDP [\%] }\end{array}$} & \multicolumn{2}{|c|}{$\begin{array}{c}\text { Expenditures (Euro) } \\
\text { per 1 000 LAG } \\
\text { population }\end{array}$} & $\begin{array}{c}\text { Share of } \\
\text { population } \\
\text { of LAGs } \\
\text { on } \\
\text { population } \\
\text { [\%] }\end{array}$ & $\begin{array}{c}\text { Number of } \\
\text { LAGs on } \\
1 \text { million } \\
\text { total } \\
\text { population }\end{array}$ & $\begin{array}{c}\text { Number of } \\
\text { projects on } \\
1000 \text { LAG } \\
\text { population }\end{array}$ \\
\cline { 2 - 5 } EU15 & 5.1 & 6.6 & 361 & 53.3 & 52.7 & 7.5 & 0.8 \\
\hline EU12 & 3.3 & 4.4 & 26.1 & 42.1 & 48.7 & 11.8 & 1.4 \\
\hline EU Total & 4.6 & 5.9 & 33.4 & 50.2 & 51.5 & 8.7 & 1.0 \\
\hline
\end{tabular}


The actual number of LAGs and the population living within their borders demonstrates another significant difference in the approach towards applying LEADER between the old and new EU member states. The relatively low number of LAGs in EU15 means that the average size of a LAG, measured by its population, is 1.7 times larger in these countries. On the one hand, the difficulty in implementing the method is greater in the new member states where a higher number of stakeholders and actors trained to implement it is needed per comparable unit (population). On the other hand, the advantage may lie in smaller groups of EU12, since a smaller community has the potential for more intense relationships and ties. The author also assumed that such a smaller community profits from a detailed knowledge of local problems and needs. As expressed by other figures, while 12 LAGs on average operate in EU12 per one million of the "rural and intermediate" population of the state, only 8 LAGs are reported in EU15 (Tab. 1). Therefore, over-proportionality of the LAGs number in EU12 and their smaller average size represent one of the main differences between the monitored EU member states.

Participatory rural development methods had a greater potential to affect the rural population of the founding and other EU15 member states, as higher confidence in this method was reflected in the available financial resources recalculated per the LAGs population and the rural population as a whole. In the newly acceded EU countries, the average amount of finances in relation to the size of the population did not reach 80 per cent (LAG population) and 75 percent (total population) of the old member states. Therefore, the lack of experience and the need to learn (Kovách, 2000; Ray, 2000), but also the lower volume of finances for the population living in the given territory limited implementation of this method in the EU member states entering the Union after 2003. Significant differences are nevertheless monitored between the EU12 countries, as Bulgaria, Estonia, Lithuania and Slovakia ranked among the ten states with the highest planned allocation in relation to the LAG population. These countries also implemented the planned funds - except from Bulgaria which had a significant delay (Fig 4).

Although the new member states could not equal the EU15 countries according to the average allocation to the LAGs, the average number of projects implemented in LAGs was almost identical. Therefore, the average level of funding allocated per one LEADER-supported project was significantly lower (less than half) in EU12. In this way, the new member states could achieve a comparable impact according to the number of the implemented projects. Similarly, the absorption capacity of territory (quantitative point of view) to meet the new challenges of rural development seems to be adequate. In the result, 38 per cent of all EU projects were implemented in EU12, while their share on the LAG and rural population was significantly lower. It is not surprising that the highest number of supported projects was recorded in Poland. Hungary reached a comparable share with Spain which was the most important among the EU15 countries. The support of broad range of projects was offset by their low average allocation in comparison to other EU countries (Fig. 5).

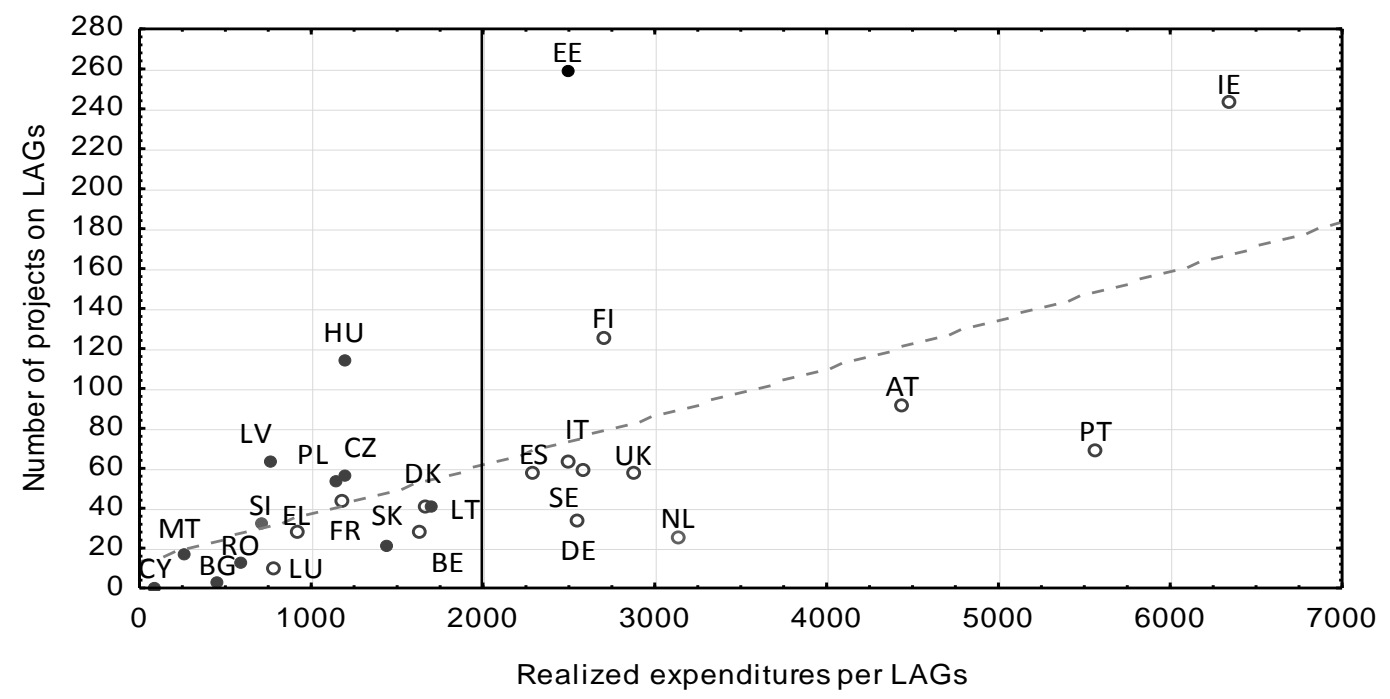

Fig 5. „Average LAG“ according to the number of projects and realized expenditures (1000 EURO) in EU in 2007-2013 (EU15 states are indicated by circle). Source: processed by author based on ENRD $2015(a, b)$ and EUROSTAT 
The larger average size of LAGs in EU15 reflects higher financial possibilities of implementing rural development support in the hands of fewer local action groups. While the more fragmented structure in the new member states meant that an average LAG operated with 1.1 million EUR, in the old EU countries, a comparable LAG utilized 2.4 times higher financial means. The price level in the EU15 countries partially eliminates this advantage (see EUROSTAT statistics Comparative price levels of consumer goods and services). Only Estonia, as a representative of EU12, ranked with the ten EU countries which recorded the highest average expenditures on LAGs, but still, an average Estonian LAG had to manage with half of the financial resources than comparable LAGs in Ireland or Portugal. This picture is slightly influenced by the low take-up rate of some EU12 countries, however also according to the planned expenditures, the difference in the average allocation of funding was more than double between the old and the new EU states.

\section{LEADER diversity in supported measures}

The differences between the monitored groups and individual states are less obvious from the point of view of the strategic decisions as to which topics should be supported via the LEADER measures. The quality of life in rural areas proved to be a key topic, since the overwhelming majority of both planned and implemented expenditures (90\%) were focused on fulfilment of the objectives connected with this measure. All EU15 member states allocate at least $3 / 4$ of the expenditures to such measures (Figure 6 and 7 ).

A more differentiated approach to selecting the LEADER measures is monitored in the new member states whose expenditures were more targeted in supporting agriculture and its competitiveness (Bulgaria, Cyprus, Hungary, Latvia and Romania). Even these countries however understood that RDP implementation through the participatory method would be the strongest in direct support of the quality of life in rural areas (85\% of allocation). Relevant regulations and decrees reduced the application of environment-friendly measures in the frame of the LEADER (Convery et al., 2010), as a significant share of resources for this particular measure was allocated only in Sweden.

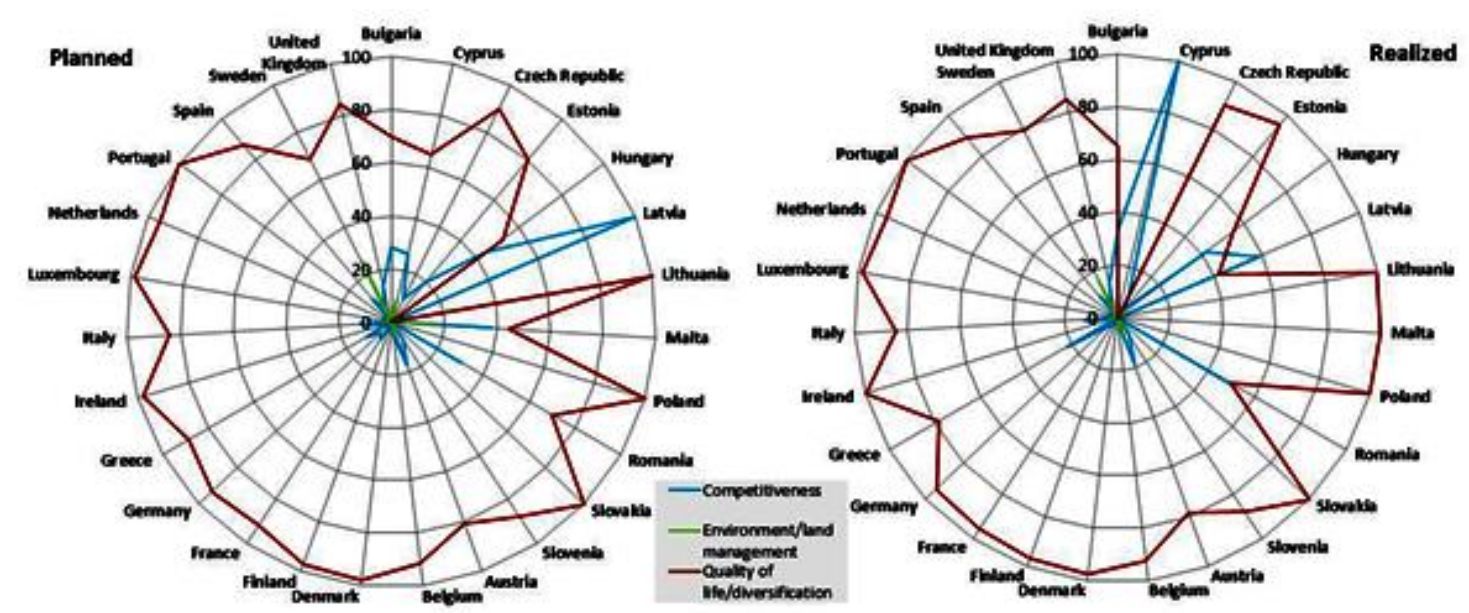

UK - United Kingdom; CZE - the Czech Republic

Fig 6., Fig 7. Planned and realized total public expenditures of Axis 4 of RDP 2007-2013 according to selected supported measures [\%]. Source: processed by author based on ENRD 2015 (a) and EUROSTAT

However, the funds earmarked for the LEADER method not always projected into improving the quality of life in rural areas or increasing the competitiveness of agricultural sector. Around $1 / 5$ of the axis funds were used to transfer and share experience through cooperation (implementing cooperation projects) and organizational maintenance of an institution implementing the LEADER method (skills acquisition, animation). Some states eventually aimed at a higher share of public funds at these two measures than at projects themselves (Figure 8); among these countries, only Luxembourg directly planned it. Mainly, the less populated countries or countries, which joined the EU in 2007 , used more than $1 / 4$ of resources to cover institutional arrangements. 
Taking into account the long-term experience with the implementation in EU15, lower amount of financial needs utilized for animation support in total expenditures could be expected. On the contrary, a higher need is understandable in the case of the new member states whose actors had to simultaneously learn to apply the method successfully and find the most appropriate mechanisms for its running and implementation. However, the mere two percentage points of lower share of expenditures on this activity within the overall spending on the method implementation in EU15 do not confirm these expectations. Although the old EU member states allocated the least amount of resources of axis 4 to this activity, many of them needed up to $1 / 5$ of the axis funding to ensure institutional implementation of the LEADER method (Finland, France, Greece, Ireland, Italy and Spain). Expenditures of the EU15 countries accounted for almost 76\% of expenditures of the EU as a whole to support the method implementation (running the LAGs, skills acquisition and animation). Therefore, it is legitimate to ask whether this (neo-endogenous) development support is sustainable in the long term, considering that even in the countries where the method was already embedded, it was necessary to spend high external costs on the running of institutions implementing LEADER in the rural space of the EU.

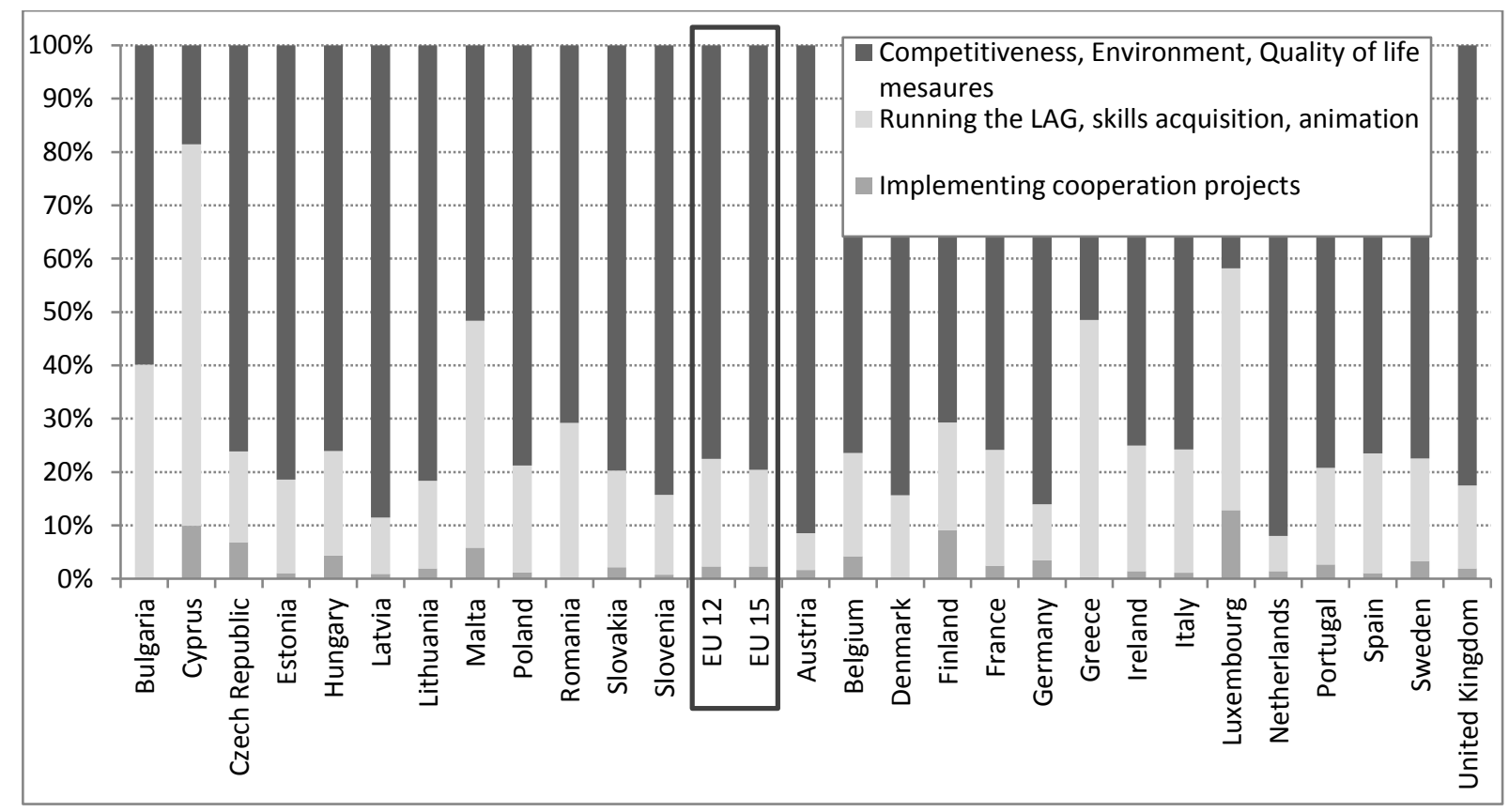

Fig 8. Realized total public expenditures of Axis 4 of RDP 2007-2013 according to all supported measures in the EU countries [\%]. Source: processed by author based on ENRD 2015 (a) and EUROSTAT

\section{Conclusion}

The EU member states joining the EU in 2004 and 2007 proved that despite the fact that the method of neo-endogenous development LEADER was not known and embedded for them, sufficient absorption capacity was built in most of them to make implementation possible in period 2004-2013. In spite of the weaker implementation experience, the new member states were almost correspondingly capable to support and institutionalize LAGs in territories where a relatively large proportion of their non-urban population lived (as in the countries with longer experience with the method implementation). It did not imply that the EU12 states were focused on LEADER so much, since the EU15 member states attributed a much larger share of finance in the frame of Rural Development Programs to this method. It was primarily the newly acceded South European countries that chose not to devote so much space to LEADER, and rather use traditional mechanisms of support through centralized institutions. However, it is necessary to emphasize that, based on the share of the allocated amount of funds for LEADER implementation within the RDP, the discussed mainstreaming of this method of rural development in the European Union is still disputable.

Participatory rural development methods had a greater potential to influence the rural population of the founding EU states and other EU15 countries as greater confidence in this method was 
reflected (as expressed via the financial amount per the LAG population, total rural population, or the average financial allocation to LAGs). It may be concluded that not only the insufficient experience, but also the lower amount of finances per inhabitant living in a given territory was the limitation of the method application in the EU member states entering the Union after 2003. Lower average size of LAGs can also be seen as a limit for the implementation in the EU12 countries, since more involved and trained actors understanding this method are needed per comparable unit (LAG). LAGs in the EU12 managed to finance a relatively comparable number of projects despite the weaker financial allocation. This concurrently means there is an increasing requirement for social capital in the region and the risk of using low-cost projects is growing. However, it can be argued that a smaller community has the potential for more intense relationships and links between actors and furthermore, smaller territories are easier to comprehend in depth and the necessary identification of local needs is subsequently more accurate. Therefore, it is important to evaluate how the lack of experience of a population with endogenous methods, low interest in participation in the development of a locality, and an increasingly regulatory environment designed by governing authorities may influence the presented advantage of smaller proportions.

The conducted research demonstrates that a pan-European program setting significantly affects the actual selection of priority measures, since the differences between the evaluated groups of states and individual countries are less evident. As a key area of rural development implemented by LEADER, states and regions decided to meet the objective of improving the quality of life. With view to the long-time discussed multifunctionality of rural areas and agriculture, prioritizing such a goal represents a positive and responsible approach to the development of rural environment. Such prioritization could partially be due to the dominance of the public sector in the LAGs bodies. Some member states joining the EU in 2004 and 2007 still attributed a major role in rural development to agriculture. Support of agriculture reflected both the relative importance of this sector for the country's rural economy and the material and capital deficiency that is still evident in agriculture of some Central, Eastern and Southern European countries. In other countries, including the Czech Republic, this approach was not accepted, as farmers themselves are not well represented in local communities. Therefore, an absorption capacity to implement agrioriented projects is lower in these countries. In other words, the difference in the strategic direction of themes supported by the LEADER method in 2007-2013 was not as large as the institutional, managerial and social differences of the functioning of the LAGs in the EU.

\section{Acknowledgements}

The research "Local development based on activities of local action groups: agriculture, local production, tourism and development of municipalities" was supported by the Internal Grant Agency (IGA) of Faculty of regional development and international studies of Mendel University in Brno (2017/20).

Academic references

[1] Arabatzis, G., Aggelopoulos, S. \& Tsiantikoudis, S. (2010). Rural development and LEADER+ in Greece: evaluation of local action groups. Journal of Food, Agriculture \& Environment, 8(1), 302-307.

[2] Böcher, M. (2008). Regional Governance and Rural Development in Germany: the Implementation of LEADER+. Sociologia Ruralis, 48(4), 372-388. DOI: 10.1111/j.14679523.2008.00468.x.

[3] Boukalova, K., Kolarova, A. \& Lostak, M. (2016). Tracing shift in Czech rural development paradigm (Reflections of Local Action Groups in the media). Agricultural Economics - Czech, 62(4), 149-159. DOI: 10.17221/102/2015-AGRICECON.

[4] Buller, H. (2000). Re-Creating Rural Territories: LEADER in France. Rural Sociology, 40(2), 190-199. DOI: 10.1111/1467-9523.00141. 
[5] Bumbalová, M., Takáč, I., Tvrdoňová, J. \& Valach, M. (2016). Are stakeholders in Slovakia ready for community-led local development? Case study findings. European Countryside, 8(2), 160-174. DOI: 10.1515/euco-2016-0013.

[6] Cañete, J. A., Navarro, F. \& Cejudo, E. (2018). Territorially unequal rural development: the cases of the LEADER Initiative and the PRODER Programme in Andalusia (Spain). European Planning Studies 26(4), 726-744. DOI: 10.1080/09654313.2018.1424118.

[7] Chevalier, P., Mačiulyté, J., Razafimahefa, L. \& Dedeire, M. (2017). The leader programme as a model of institutional transfer: learning from its local implementation in France and Lithuania. European Countryside 9(2), 317-341. DOI: 10.1515/euco-2017-0020.

[8] Chevalier, P. \& Maurel, M.-C. (2010). Program leader w krajach europy srodkowej. Wieś I Rolnictwo, 149(4), 26-41.

[9] Chevalier, P. (2012). What effect does national regulation have on LEADER programming in the EU-27? Wieś I Rolnictwo, 156(3), 9-29.

[10] Convery, I., Soane, I., Dutson, T. \& Shaw, H. (2010). Mainstreaming LEADER Delivery of the RDR in Cumbria: An Interpretative Phenomenological Analysis. Sociologia Ruralis, 50(4), 372-391. DOI: 10.1111/j.1467-9523.2010.00519.x.

[11] Dargan, L. \& Shucksmith, M. (2008). LEADER and Innovation. Sociologia Ruralis, 48(3), 274-291. DOI: 10.1111/j.1467-9523.2008.00463.x.

[12] Dax, T. \& Oedl-wieser, T. (2016). Rural innovation activities as a means for changing development perspectives - An assessment of more than two decades of promoting LEADER initiatives across the European Union. Studies in Agricultural Economics, 118, 3037. DOI: $10.7896 / \mathrm{j} .1535$.

[13] Dax, T., Strahl, W., Kirwan, J. \& Maye, D. (2016). The Leader programme 2007-2013: Enabling or disabling social innovation and neo-endogenous development? Insights from Austria and Ireland. European Urban and Regional Studies, 23(1), 56-68. DOI: $10.1177 / 0969776413490425$.

[14] Delin, M. (2012). The role of farmers in Local Action Groups: The case of the national network of the Local Action Groups. Agricultural Economics - Czech, 58(9), 433-442.

[15] Fakowski, J. (2013). Political accountability and governance in rural areas: Some evidence from the Pilot Programme LEADER+ in Poland. Journal of Rural Studies, 32, 70-79. DOI: 10.1016/j.jurstud.2013.04.008.

[16] Furmankiewicz, M. (2012). Leader+ territorial governance in Poland: successes and failures as a rational choice effect. Tijdschrift Voor Economische en Sociale Geografie, 103(3), 261275. DOI: 10.1111/j.1467-9663.2011.00680.x.

[17] Furmankiewicz, M., Thompson, N. \& Zielin, M. (2010). Area-based partnerships in rural Poland: The post-accession experience. Journal of Rural Studies, 26(1), 52-62. DOI: 10.1016/j.jurstud.2009.05.001.

[18] Granberg, L., Andersson, K., Kovách, I. eds. (2015). Evaluating the European Approach to Rural Development: Grassroots Experiences of the LEADER Programme. Farnham: Ashgate.

[19] Hudečková, H. \& Lošták, M. (2008). LEADER in the Czech Republic and the farming sector. Agricultural Economics - Czech, 54(12), 555-565.

[20] Jančák, V., Chromý, P., Marada, M., Havlíček, T. \& Vondráčková, P. (2010). Sociální kapitál jako faktor rozvoje periferních oblastí: Analýza vybraných složek sociálního kapitálu v typově odlišnŷh periferiích Česka. Geografie, 115(2), 207-222.

[21] Kovách, I. (2000). LEADER, a New Social Order, and the Central- and East-European Countries. Sociologia Ruralis, 40(2), 181-189. DOI: 10.1111/1467-9523.00140. 
[22] Lošták, M. \& Hudečková, H. (2008). Agriculture and farming related activities: their actors and position in the LEADER approach. Agricultural Economics - Czech, 54(6), 245-262.

[23] Lošták, M., \& Hudečková, H. (2010). Preliminary impacts of the LEADER+ approach in the Czech Republic. Agricultural Economics - Czech, 56(6), 249-265.

[24] Lowe, P. (2000). The Challenges for Rural Development in Europe. In: Williams, E., ed., Conference Proceedings: $5^{\text {th }}$ European Conference on Higher Agricultural Education. From Production Agriculture to Rural Development (pp. 19-31). University of Plymouth.

[25] Lukić, A. \& Obad, O. (2016). New Actors in Rural Development - The LEADER Approach and Projectification in Rural Croatia. Sociologija I Prostor, 54(1), 71-90. DOI: $10.5673 /$ sip.54.1.4.

[26] Macken-Walsh, A. \& Curtin, C. (2012). Governance and Rural Development: The Case of the Rural Partnership Programme (RPP) in Post-Socialist Lithuania. Sociologia Ruralis, 53(2), 246-264. DOI: 10.1111/j.1467-9523.2012.00578.x.

[27] Majerová, V. (2009). Local Initiatives Functioning as a Condition of Rural Development of the Czech Countryside. Eastern European Countryside, 9(1), 127-149. DOI: 10.2478/v10130009-0008-2.

[28] Margarian, A. (2013). A Constructive Critique of the Endogenous Development. Approach in the European Support of Rural Areas. Growth and Change, 44(1), 1-29. DOI: 10.1111 /grow.12000.

[29] Marquardt, D., Möllers, J. \& Buchenrieder, G. (2012). Social Networks and Rural Development: LEADER in Romania. Sociologia Ruralis, 52(4), 398-431. DOI: 10.1111/j.1467-9523.2012.00571.x.

[30] Masot, A. N. \& Alonso, G. C. (2017). 25 years of the leader initiative as European rural development policy: the case of Extremadura (SW Spain). European Countryside 9(2), 302316. DOI: 10.1515/euco-2017-0019.

[31] Maurel, M.-C. (2008). Local development stakeholders and the European model: learning the leader approach in the new member states. Sociologicky časopis, 44(3), 511-529.

[32] Navarro, F. A., Woods, M. \& Cejudo, E. (2015). The LEADER Initiative has been a Victim of its own Success. The Decline of the Bottom-Up Approach in Rural Development Programmes. The Cases of Wales and Andalusia. Sociologia Ruralis 56(2), 270-288. DOI: $10.1111 /$ soru.12079.

[33] Nevěděl, L. \& Horák, M. (2015). Operation of the selected local action group. Acta Universitatis Agriculturae et Silviculturae Mendelianae Brunensis, 63(1), 347-352. DOI: 10.11118/actaun201563010347.

[34] Osti, G. (2000). LEADER and partnerships: the case of Italy. Sociologia Ruralis, 40(2), 172180. DOI: 10.1111/1467-9523.00139.

[35] Papadopoulou, E., Hasanagas, N. \& Harvey, D. (2011). Analysis of rural development policy networks in Greece: Is LEADER really different? Land Use Policy, 28(4), 663-673. DOI: 10.1016/j.landusepol.2010.11.005.

[36] Perlín, R., Kučerová, S. \& Kučera, Z. (2010). Typologie venkovského prostoru Česka. Geografie, 115(2), 161-187.

[37] Pisani, E., Franceschetti, G., Secco, L., Christoforou, A., eds. (2017). Social Capital and Local Development: From Theory to Empirics. Cham: Springer.

[38] Pollermann, K., Raue, P. \& Schnaut, G. (2013). Rural Development experiences in Germany: opportunities and obstacles in fostering smart places through LEADER. Studies in Agricultural Economics, 115(2), 1-7. 
[39] Pospěch, P. (2014). Discursive no man's land: Analysing the discourse of the rural in the transitional Czech Republic. Journal of Rural Studies, 34, 96-107. DOI: 10.1016/j.jrurstud.2014.01.006.

[40] Ray, C. (2000). The EU LEADER Programme: Rural Development Laboratory. Sociologia Ruralis 40(2), 163-171. DOI: 10.1111/1467-9523.00138.

[41] Rizzo, F. (2013). Leader Policy Practices and Landscapes in the Light of the AgencyStructure Debate: Evidence from Leader Local Action Groups in Italy and in Finland. European Countryside 5(3), 232-250. DOI: 10.2478/euco-2013-0015.

[42] Svobodová, H. (2015). Do the Czech local action groups respect the leader method? Acta Universitatis Agriculturae et Silviculturae Mendelianae Brunensis, 63(5), 1769-1777. DOI: 10.11118/actaun201563051769.

[43] Št'astná, M. \& Vaishar, A. (2017). The relationship between public transport and the progressive development of rural areas. Land Use Policy, 67, 107-114. DOI: 10.1016/j.landusepol.2017.05.022.

[44] Thuesen, A. A. \& Nielsen, N. C. (2014). A territorial perspective on EU's leader approach in Denmark: the added value of community-led local development of rural and coastal areas in a multi-level governance settings. European Countryside 6(4), 307-326. DOI: https://doi.org/10.2478/euco-2014-0017.

[45] Volk, A. \& Bojnec, Š. (2014). Local action groups and the LEADER co-financing of rural development projects in Slovenia. Agricultural Economics - Czech, 60(8), 364-375.

[46] Tulla, A. F., Vera, A., Valldeperas, N. \& Guirado, C. (2017). New approaches to sustainable rural development: Social farming as an opportunity in Europe? Human Geographies Journal of Studies and Research in Human Geography, 11(1), 2067-2284. DOI: 10.5719/hgeo.2017.111.2.

[47] Woods, M. \& Mcdonagh, J. (2011). Europe and the world: globalization and rural development (editorial). European Countryside 3(3), 153-163. DOI: 10.2478/v10091-0120001-z.

\section{Other sources}

[48] European Network for Rural Development (2015a). Financial and physical indicators 20072013. Available at: http://enrd.ec.europa.eu/policy-in-action/rural-development-policy-infigures/rdp-monitoring-indicator-tables/financial-and-physical-indicators_en. Accessed on 1 st March 2017.

[49] European Network for Rural Development (2015b). Output indicators 2007-2013. Available

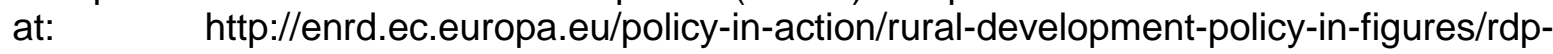
monitoring-indicator-tables/output-indicators_en). Accessed on 1st March 2017.

[50] EUROSTAT (2017a). Eurostat regional yearbook - 2017 edition. Luxembourg: Publications Office of the European Union.

[51] EUROSTAT (2017b). Statistics - Comparative price levels of consumer goods and services. Available at: http://ec.europa.eu/eurostat/statisticsexplained/index.php/Comparative_price_levels_of_consumer_goods_and_services). Accessed on 6th March 2018.

[52] EUROSTAT (2018). Territorial typologies. Available at: http://ec.europa.eu/eurostat/statistics-explained/index.php/Territorial_typologies. Accessed on 13th February 2018. 